\title{
Systèmes techniques de production lithique
}

Variations techno-économiques dans les processus de réalisation des outillages paléolithiques

Jean-Michel Geneste

\section{(2) OpenEdition}

12 Journals

Édition électronique

URL : https://journals.openedition.org/tc/683

DOI : $10.4000 /$ tc. 683

ISSN : 1952-420X

Éditeur

Éditions de l'EHESS

Édition imprimée

Date de publication : 1 novembre 1992

ISSN : 0248-6016

\section{Référence électronique}

Jean-Michel Geneste, "Systèmes techniques de production lithique », Techniques \& Culture [En ligne], 17-18 | 1992, mis en ligne le 10 janvier 2006, consulté le 29 septembre 2022. URL : http:// journals.openedition.org/tc/683; DOI : https://doi.org/10.4000/tc.683

Ce document a été généré automatiquement le 29 septembre 2022.

Tous droits réservés 


\section{Systèmes techniques de production lithique}

Variations techno-économiques dans les processus de réalisation des outillages paléolithiques

Jean-Michel Geneste 